\title{
EKSTRAK DAUN SIRIH HIJAU DAN MERAH SEBAGAI ANTIOKSIDAN PADA MINYAK KELAPA
}

\author{
Hermiati, Rusli, Naomi Yemima Manalu, Mersi Suriani Sinaga \\ Departemen Teknik Kimia, Fakultas Teknik, Universitas Sumatera Utara, \\ Jl. Almamater Kampus USU Medan 20155, Indonesia \\ E-mail: hermiati@students.usu.ac.id
}

\begin{abstract}
Abstrak
Ekstraksi adalah pemisahan suatu zat dari campurannya, dengan pembagian sebuah zat terlarut antara dua pelarut yang tidak dapat tercampur untuk mengambil zat terlarut tersebut dari satu pelarut ke pelarut yang lain. Tujuan dari penelitian ini adalah untuk mengetahui aktivitas antioksidan yang terdapat pada ekstrak daun sirih untuk minyak kelapa dengan analisa bilangan peroksida, ketahanan antioksidan, uji warna dengan lovibond dan menemukan variasi jenis daun sirih yang menghasilkan kondisi operasi antioksidan yang optimum. Dalam penelitian ini, daun sirih hijau dan merah diekstrak dengan menggunakan pelarut etanol, hasil ekstrak akan ditambahkan ke minyak kelapa lalu diuji bilangan peroksidanya dan kadar warnanya. Hasil yang diperoleh pada penelitian ini adalah daun sirih dapat menurunkan bilangan peroksida sebesar 55,13\% dengan keadaan optimum terbaik; volume pelarut $150 \mathrm{ml}$, waktu ekstraksi 75 menit, dan kecepatan pengadukan 300 rpm untuk bahan baku serbuk daun sirih merah.
\end{abstract}

Kata kunci: ekstraksi, antioksidan, bilangan peroksida, sirih, lovibond

\begin{abstract}
Extraction is the separation of a substance from the mixture, with the distribution of a solute between two solvents which can not be mixed to fetch solute from one solvent to another solvent. The purpose of this study was to determine the antioxidant activity found in betel leaf extract for coconut oil numbers peroxide analysis, antioxidant resistance, with Lovibond color test and to found variations in betel leaf types that produce the optimum operating conditions of antioxidants. In this study, green and red betel leaves extracted by using ethanol solvent, the extract is added to coconut oil and then tested peroxide number and color levels. The results obtained in this study were able to lower the number of betel leaves peroxide by $55.13 \%$ with the best optimum condition; volume of $150 \mathrm{ml}$ of solvent, extraction time of 75 minutes, and stirring speed of 300 rpm for the raw material powder of red betel leaf.
\end{abstract}

Keywords : extraction, antioxidants, peroxide number, betel, lovibond

\section{Pendahuluan}

\section{Latar Belakang}

Pembudidayaan minyak kelapa banyak dilakukan oleh penduduk Indonesia. Minyak kelapa yang memiliki nilai jual yang tinggi sehingga perlu dijaga kualitasnya dari permasalahan pada saat tahap penyimpanan minyak kelapa ini karena minyak kelapa mengandung zat-zat radikal bebas yang dapat menyebabkan bau tengik pada minyak kelapa yang sudah diproduksi.

Antioksidan adalah senyawa yang secara alami terdapat dalam hampir semua bahan makanan, karena bahan makanan dapat mengalami degradasi baik secara fisik maupun kimia sehingga fungsinya berkurang, untuk itu perlu ditambahkan antioksidan dari luar untuk melindungi bahan makanan dari reaksi oksidasi. Antioksidan diperlukan untuk mengawetkan makanan yang mengandung minyak atau lemak dengan nilia gizi dari makanan itu tidak berkurang.
Antioksidan di golongkan menjadi dua jenis yaitu antioksidan alami dan sintetis, penggunaan anitoksidan sintetis seperti BHA (Butil Hidroksi Anisol) dan BHT (Butil Hidroksi Toulene) sangat efektif untuk menghambat minyak atau lemak agar tidak terjadi oksidasi. Tetapi penggunaan BHA dan BHT banyak menimbulkan kekhawatiran akan efek sampingnya [2]. Beberapa hasil studi laboratorium yang dilakukan pada hewan menunjukkan kalau BHA dan BHT bisa menyebabkan kanker dan tumor. Selain itu, ada bukti yang mendukung kalau kedua pengawet ini menyebabkan gangguan metabolisme pada manusia [3].

Kekhawatiran akan efek samping antioksidan sintetis mendorong para ahli kimia untuk mencari antioksidan alami yang lebih aman. Antioksidan yang saat ini banyak digunakan diambil dari bahan rempah - rempah karena di rempah - rempah amat berbau dan berasa sehingga mempengaruhi aroma dan rasa 
sehingga perlu dicari antioksidan yang aman tetapi tidak banyak berpengaruh terhadap aroma dan rasa makanan.

Tanaman sirih banyak terdapat di Indonesia dan tanaman ini tidak memerlukan penanganan khusus dalam pembudidayaannya. Akan tetapi sampai saat ini pemanfaatan daun sirih masih belum optimal. Salah satu manfaat daun sirih adalah sebagai antioksidan pada makanan, terutama pada makan yang mengandung minyak dan lemak [2].

Penggunaan daun sirih hijau sebagai antioksidan pada minyak kelapa telah diuji dan telah menunjukkan hasil yang baik. Tetapi daun sirih merah masih merupakan tanaman yang baru sebagai alternatif antioksidan sehingga perlu dilakukan penilitian lebih lanjut untuk mengetahui apakah daun sirih merah memiliki kemampuan yang lebih baik sebagai antioksidan pada minyak kelapa dibandingkan dengan daun sirih hijau.

Adapun hasil dari penelitian sebelumnya oleh Anie Komayaharti dan Dwi Paryanti diperoleh kesimpulan bahwa variabel yang paling berpengaruh adalah volume solvent yaitu etanol. Dimana variasi variabel yang digunakan pada percobaan adalah waktu ekstraksi (30 menit dan 90 menit), volume solvent (50 ml dan 150 $\mathrm{ml}$ ) dan kecepatan pengadukan (200 rpm dan $1200 \mathrm{rpm})$. Dan penelitian yang akan kita lakukan ini merupakan lanjutan dari penelitian selanjutnya dengan variasi variabel dan analisa yang lebih banyak.

\section{Perumusan Masalah}

Rumusan masalah dalam penelitian ini adalah bagaimana pengaruh variasi bahan baku (daun sirih hijau, daun sirih merah, serbuk sirih hijau, serbuk sirih merah), waktu ekstraksi, volume solvent dan variasi kecepatan pengadukan dalam pengaruh aktivitas antioksidan ekstrak daun sirih dengan analisa bilangan peroksida pada minyak kelapa, ketahanan antioksidan dan uji warna dengan lovibond .

\section{Tujuan Penelitian}

Penelitian ini bertujuan untuk mengetahui aktivitas antioksidan yang terdapat pada ekstrak daun sirih untuk minyak kelapa dengan analisa bilangan peroksida, ketahanan antioksidan, uji warna dengan lovibond dan menemukan variasi jenis daun sirih mana yang menghasilkan kondisi operasi antioksidan yang optimum.

\section{Teori}

1. Daun Sirih
1.1 Daun Sirih Hijau
Sirih merupakan tanaman asli Indonesia yang tumbuh merambat atau bersandar pada batang pohon lain. Sebagai budaya daun dan buahnya biasa dimakan dengan cara mengunyah bersama gambir, pinang dan kapur. Namun mengunyah sirih telah dikaitkan dengan penyakit kanker mulut dan pembentukan squamous cell carcinoma yang bersifat malignan. Sirih digunakan sebagai tanaman obat (fitofarmaka); sangat berperan dalam kehidupan dan berbagai upacara adat rumpun Melayu [10].

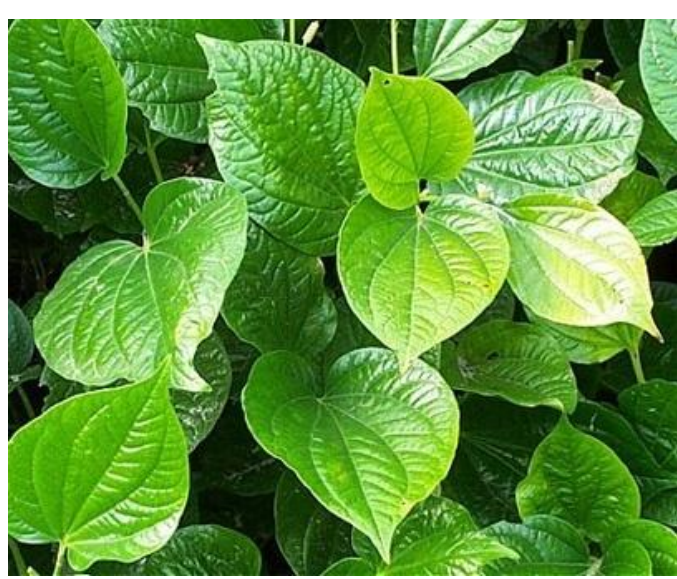

\section{Gambar 1. Daun Sirih Hijau}

\subsection{Daun sirih Merah}

Tanaman sirih merah (Piper crocatum) termasuk dalam famili Piperaceae, Tanaman ini tumbuh di berbagai daerah di Indonesia, seperti Papua, Aceh, Yogyakarta, dan Jawa Barat. Batangnya bulat berwarna hijau keunguan dan tidak berbunga. Daunnya berbentuk jantung dengan bagian ujung meruncing. Panjang daun bisa meneapai $15-20 \mathrm{~cm}$. Warna ujung daun hijau bersaput putih keabu-abuan. Bagian pangkal daun berwarna merah hati. Daunnya berlendir, berasa sangat pahit, dan beraroma wangi khas sirih.

Sirih merah tergolong langka karena tidak tumbuh di setiap tempat. Bisa tumbuh dengan baik di tempat yang teduh dan tidak terlalu banyak terkena sinar matahari. Jika terkena sinar matahari langsung pada siang hari seeara terusmenerus warna merah daunnya bisa menjadi pudar, buram, dan kurang menarik.

Tanaman ini juga pantang kelebihan air. Karena itu, pada musim penghujan banyak yang mati akibat batangnya membusuk dan daunnya rontok. Sirih merah akan tumbuh dengan baik bila mendapat $60-75 \%$ cahaya matahari. Karena itu perlakuan khusus sangat dibutuhkan dalam upaya menjaga syarat tumbuh. Banyak orang mengoleksi tanaman sirih merah, tetapi tidak 
banyak yang mengerti perawatannya, sehingga cepat mati.

Dari hasil penelitian diketahui daun sirih merah mengandung flavanoid, polevenolad, tanin, dan minyak atsiri. Secara empiris zat aktif itu memiliki efek mencegah ejakulasi dini, antikejang, membasmi kuman, penghilang rasa nyeri dan.menghilangkan bengkak. Di samping itu bisa juga untuk mengatasi radang paru, radang tenggorokan, gusi bengkak, radang payudara, hidung mimisan, kencing manis, ambeien, jantung koroner, darah tinggi, asam urat: dan batuk berdarah [6].

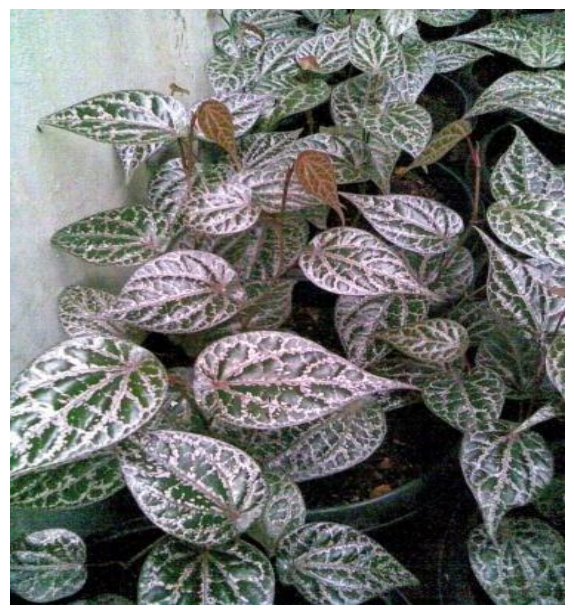

Gambar 2. Daun Sirih Merah

\section{Antioksidan}

Ketengikan merupakan masalah yang sangat menentukan mutu produk pangan. Salah satu cara untuk mengatasinya ialah dengan menambahkan antioksidan. Dewasa ini penggunaan antioksidan untuk keperluan industri pangan semakin meningkat dan telah diketahui bahwa antioksidan sintetik sangat efektif dalam menghambat reaksi oksidasi lemak sehingga dapat mencegah terjadinya ketengikan produk. Akan tetapi, penggunaan antioksidan sintetik dikhawatiran menimbulkan efek patologi. Hal ini mendorong konsumen untuk memilih produk alami yang harus segera diantisipasi oleh para pakar teknologi pangan [1].

Senyawa antioksidan alami tumbuhan umumnya adalah senyawa fenolik atau polifenolik yang dapat berupa golonganflavonoid, turunan asam sinamat, kumarin, tokoferol, dan asam-asam organic polifungsional. Golongan flavonoid yang memiliki aktivitas antioksidan meliputi flavon, flavonol, isoflavon, kateksin, flavonol dan kalkon. Sementara turunan asamsinamat meliputi asam kafeat, asam ferulat, asam klorogenat, dan lain-lain.
Senyawa antioksidan alami polifenolik ini adalah multifungsional dan dapat beraksi sebagai pereduksi, penangkap radikal bebas, pengkelat logam, peredam terbentuknya singlet oksigen. Kira-kira $2 \%$ dari seluruh karbon yang difotosintesis oleh tumbuhan diubah menjadi flavonoid atau senyawa yang berkaitan erat dengannya, sehingga flavonoid merupakan salah satu golongan fenol alam terbesar. Sebenarnya flavonoid terdapat dalam semua tumbuhan hijau, sehingga pastilah ditemukan pula pada setiap telaah ekstrak tumbuhan. Golongan flavonoid dan senyawa yang berkaitan erat dengannya memiliki sifat-sifat antioksidan baik didalam lipida cair maupun dalam makanan berlipida [8].

\section{Ekstraksi}

Ekstraksi adalah pemisahan suatu zat dari campurannya dengan pembagian sebuah zat terlarut antara dua pelarut yang tidak dapat tercampur untuk mengambil zat terlarut tersebut dari satu pelarut ke pelarut yang lain. Sering kali campuran bahan padat dan cair (misalnya bahan alami) tidak dapat atau sukar sekali dipisahkan dengan metode pemisahan mekanis atau termis yang telah dibicarakan. Misalnya saja,karena komponennya saling bercampur secara sangat erat, peka terhadap panas,beda sifat-sifat fisiknya terlalu kecil, atau tersedia dalam konsentrasi yang terlalu rendah [7]

\section{Ketengikan}

Penyebab ketengikan dalam lemak dibagi atas tiga golongan, yaitu :

1. Ketengikan oleh oksidasi (oxidative rancidity). Kerusakan lemak yang utama adalah timbulnya bau dan rasa tengik yang disebut proses ketengikan. Hal ini disebabkan oleh otooksidasi radikal asam lemak tidak jenuh dalam lemak. Otooksidasi dimulai dengan pembentukan radikal-radikal bebas yang disebabkan oleh faktor-faktor yang dapat mempercepat reaksi seperti cahaya, panas, peroksida lemak atau hidroperoksida, logamlogam berat seperti $\mathrm{Cu}, \mathrm{Fe}, \mathrm{Co}$, dan $\mathrm{Mn}$, logam porfirin seperti hematin, hemoglobin, mioglobin, klorofil, dan enzim-enzim lipoksidase.

\section{Ketengikan oleh enzim (enzymatic rancidity).}

Bahan pangan berlemak dengan kadar air dan kelembaban udara tertentu, merupakan medium yang baik bagi pertumbuhan jamur. Jamur tersebut mengeluarkan enzim, misalnya enzim lipo clastic dapat meguraikan trigliserida menjadi asam lemak bebas dan gliserol [4]. 
Enzim peroksida dapat mengoksidasi asam lemak tidak jenuh sehingga terbentuk peroksida. Disamping itu enzim peroksida dapat mengoksidasi asam lemak jenuh pada ikatan karbon atom $\beta$, sehingga membentuk asam keton dan akhirnya metil keton.

3. Ketengikan oleh proses hidrolisa (hidrolitic rancidity).

Dalam reaksi hidrolisa, minyak atau lemak akan diubah menjadi bermacam-macam asam lemak bebas dan gliserol. Reaksi hidrolisa yang dapat mengakibatkan kerusakan minyak atau lemak ini terjadi karena adanya kandungan air dalam minyak atau lemak, yang pada akhirnya menyebabkan ketengikan dengan perubahan rasa dan bau pada minyak tersebut.

Berbagai jenis minyak atau lemak akan mengalami perubahan flavor dan bau sebelum terjadi proses ketengikan, ini dikenal sebagai reversion. Beberapa peneliti berpendapat bahwa hal ini khas pada minyak atau lemak. Reversion terutama dijumpai dalam lemak dipasar dan pada pemanggangan atau penggorengan dengan menggunakan temperatur yang terlalu tinggi.

Ketengikan berbeda dengan reversion. Beberapa minyak atau lemak mudah terpengaruh untuk menjadi tengik tapi akan mempunyai daya tahan terhadap peristiwa reversion, misalnya pada minyak jagung. Perubahan flavor yang terjadi selama reversion berbeda untuk setiap jenis minyak. Sedangkan minyak yang telah menjadi tengik akan menghasilkan flavor yang sama untuk semua jenis minyak atau lemak. Bilangan peroksida yang sangat tinggi dapat menjadi indikasi ketengikan minyak atau lemak, tetapi bilangan peroksida ini tidak mempunyai hubungan dengan peristiwa reversion [4].

\section{Standar Mutu Minyak Kelapa}

Tabel 1. Standar Mutu Minyak Kelapa [9].

\begin{tabular}{|c|l|c|}
\hline No & \multicolumn{1}{|c|}{ Kriteria } & Persyaratan \\
\hline 1 & Bau dan Rasa & Normal \\
\hline 2 & Warna & Muda Jernih \\
\hline 3 & Kadar Air & Max 0,3\% \\
\hline 4 & Berat Jenis & $0,900 \mathrm{~g} / \mathrm{liter}$ \\
\hline 5 & Asam lemak bebea & Max 0,3\% \\
\hline 6 & Bilangan Perioksida & Max $2 \mathrm{Meg} / \mathrm{kg}$ \\
\hline 7 & Bilangan Iod & $45-46$ \\
\hline 8 & Bilangan Penyabunan & $196-206$ \\
\hline 9 & Index Bias & $1,448-1,450$ \\
\hline 10 & Cemaran Logam & $\begin{array}{c}\text { Max } 0,1 \mathrm{mg} / \mathrm{kg} \\
\text { Kecuali Seng }\end{array}$ \\
\hline
\end{tabular}

\section{Metodologi Penelitian}

1. Lokasi Penelitian

Penelitian ini dilakukan di Laboratorium Penelitian, Jurusan Teknik Kimia, Fakultas Teknik, Universitas Sumatera Utara.

2. Sampling

Sampel yang digunakan pada penelitian ini adalah daun sirih merah dan daun sirih hijau yang diambil dari hasil budidaya salah satu peneliti.

3. Prosedur Penelitian

3.1 Prosedur Persiapan Bahan Baku

3.1.1 Prosedur Pembuatan Serbuk Sirih

1. Sampel (daun sirih segar) ditimbang sebanyak 100 gram kemudian dijemur hingga kering.

2. Setelah benar-benar kering, sampel dihancurkan dengan menggunakan blender.

3. Diayak dengan menggunakan ayakan 50 Mesh, hingga diperoleh serbuk sirih.

4. Divariasikan jenis sampel.

3.1.2 Prosedur Pembuatan Sirih Segar Cacah

1. Sampel (daun sirih segar) ditimbang sebanyak 100 gram .

2. Sampel dihancurkan dengan cara dipotong kecil-kecil (dicacah).

3. Divariasikan jenis sampel.

3.2 Prosedur Ekstraksi Antioksidan pada Daun Sirih

1. Ditimbang serbuk sirih sebanyak 5 gram masukan kedalam labu leher tiga.

2. Ditambahkan pelarut etanol $96 \%$ sebanyak $100 \mathrm{ml}$ ke dalam beaker glass dan diaduk, lalu dimasukkan ke labu leher tiga.

3. Alat ekstraksi dirangkai.

4. Magnetik Stirrer dimasukkan ke labu leher tiga dan diatur kecepatannya sebesar $100 \mathrm{rpm}$.

5. Hot Plate dihidupkan dan diatur suhunya sebesar $60{ }^{\circ} \mathrm{C}$.

6. Dibiarkan lama ekstraksi selama 30 menit.

7. Hot Plate dimatikan dan hasil ekstrak dituangkan ke beaker glass.

8. Ekstrak diambil dengan cara filtrasi, hasil ekstrak disaring dengan kertas saring dan residu dibuang.

9. Hasil filtrasi yaitu filtrat dipekatkan dengan oven, pada suhu $40^{\circ} \mathrm{C}$ selama 1 jam sehingga diperoleh filtrat pekat.

10. Percobaan diulangi dengan variasi bahan baku (serbuk kering sirih merah, serbuk kering sirih hijau, daun sirih merah segar cacah dan daun sirih hijau segar cacah), variasi jumlah pelarut $(100 \mathrm{ml}, 150 \mathrm{ml}$ dan $200 \mathrm{ml}$ ), variasi kecepatan pengadukan (100 rpm dan $300 \mathrm{rpm}$ ) dan lama ekstraksi 30 
menit, 45 menit, 60 menit, 75 menit dan 90 menit).

3.3 Prosedur Analisa Bilangan Peroksida

1. Minyak kelapa diambil seberat $5 \mathrm{ml}$ didalam Erlenmeyer.

2. Tambahkan ektrak daun sirih sebanyak $5 \mathrm{ml}$.

3. Kemudian tambahkan $30 \mathrm{ml}$ campuran asam asetat glasial dan kloroform 3:2 lalu larutan dikocok sampai semuanya larut ( $18 \mathrm{ml}$ asam asetat glasial dan $12 \mathrm{ml}$ kloroform )

4. Tambahkan 1 gr padatan KI diaduk rata dan larutan akan berubah menjadi warna kuning.

5. Lalu tambahkan $30 \mathrm{ml}$ aquades kemudian dititrasi dengan larutan $\mathrm{Na}_{2} \mathrm{~S}_{2} \mathrm{O}_{3} \quad 0,1 \quad \mathrm{~N}$ sampai larutan berwarna kuning pucat.

6. Tambahkan 0,5 ml larutan amilum kental, larutan akan berubah menjadi warna ungu pucat dan titrasi dilanjutkan sampai warna biru hilang.

Bilangan Perioksida $=$

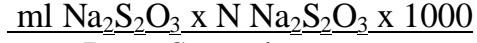
Berat Sampel

3.4 Prosedur Analisa Bilangan Peroksida untuk Mengetahui Ketahanan Antioksidan

1. Minyak kelapa diambil seberat $20 \mathrm{ml}$ didalam Erlenmeyer.

2. Tambahkan ektrak daun sirih sebanyak $20 \mathrm{ml}$.

3. Biarkan campuran minyak kelapa tersebut selama 3 hari.

4. Setelah setelah 3 hari, diambil ambil $10 \mathrm{ml}$ campuran minyak kelapa.

5. Kemudian dilakukan Analisa Bilangan Peroksida

6. Prosedur no.5 dilakukan dengan variasi waktu 6 hari, 9 hari, dan 12 hari.

7. Prosedur no1-6 dilakukan untuk variasi sampel lain

3.5 Prosedur Uji Warna dengan Lovibond

1. Diambil sampel hasil pencampuran 1:1 antara minyak kelapa dan antioksidan daun sirih hijau sebanyak $10 \mathrm{ml}$.

2. Dimasukkan sampel ke dalam gelas kaca khusus, tambahkan reagen warna dan diletakkan pada mesin Lovibond.

3. Dihidupkan Mesin Lovibond.

4. Bandingan warna sampel dengan warna pada cakram warna yang terdapat pada alat.

5. Baca dan catat kandungan zat warna yang terkandung dalam sampel tersebut.

6. Prosedur no.1-4 diulang dengan antioksidan dari daun sirih hijau.

\section{Hasil}

1.1 Bahan Baku Serbuk Kering Daun Sirih Hijau

\subsubsection{Pengaruh Volume Pelarut Terhadap}

Bilangan Peroksida

Grafik-grafik di bawah (Gambar 3 dan Gambar 4) menunjukkan pengaruh volume pelarut dan waktu ekstraksi terhadap bilangan peroksida. Volume pelarut dapat mempengaruhi banyaknya antioksidan yang diperoleh dari ekstraksi serbuk kering daun sirih hijau pada kecepatan pengadukan $100 \mathrm{rpm}$ dan $300 \mathrm{rpm}$. Semakin rendah bilangan peroksida yang diperoleh berarti antioksidan yang dihasilkan dari ekstrak serbuk kering daun sirih itu tinggi.

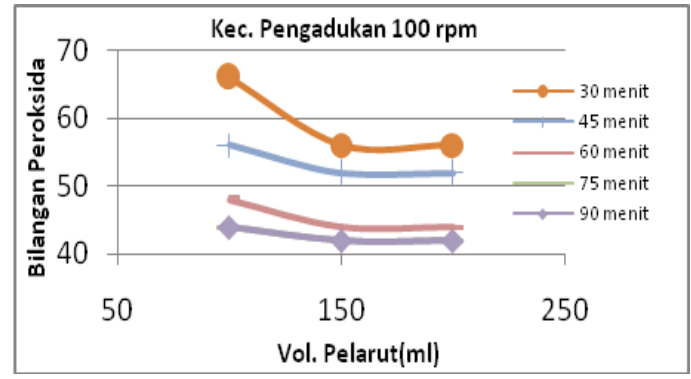

Gambar 3. Grafik Pengaruh Volume Pelarut terhadap Bilangan Peroksida pada Serbuk Kering Daun Sirih Hijau (Kecepatan Pengadukan 100 rpm).

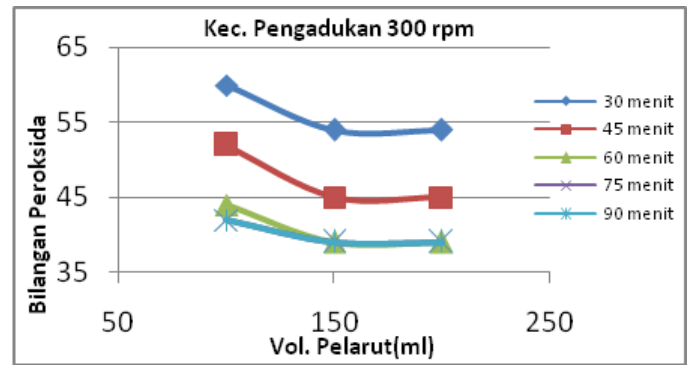

Gambar 4. Grafik Pengaruh Volume Pelarut terhadap Bilangan Peroksida pada Serbuk Kering Daun Sirih Hijau (Kecepatan Pengadukan 300 rpm).

Untuk mengetahui pengaruh volume pelarut terhadap bilangan peroksida dengan kecepatan pengadukan $100 \mathrm{rpm}$ dan $300 \mathrm{rpm}$ pada serbuk kering daun sirih hijau, dilakukan sejumlah percobaan dengan variasi volume pelarut (v) 100 $\mathrm{ml}, 150 \mathrm{ml}$, dan $200 \mathrm{ml}$ dengan waktu (t) antara: 30 menit, 45 menit, 60 menit, 75 menit, dan 90 menit.

Pada kecepatan pengadukan $100 \mathrm{rpm}$ dengan variasi waktu ekstraksi 30 menit, 45 menit, dan 60 menit diperoleh penurunan bilangan peroksida yang tidak terlalu signifikan. Sedangkan untuk variasi waktu ekstraksi 75 menit diperoleh bilangan peroksida terkecil yaitu $42 \mathrm{Meq} / \mathrm{kg}$ pada volume pelarut $150 \mathrm{ml}$.

Pada kecepatan pengadukan $300 \mathrm{rpm}$ dengan variasi waktu 30 menit dan 45 menit diperoleh penurunan bilangan peroksida yang 
tidak terlalu signifikan. Sedangkan untuk variasi waktu 60 menit diperoleh bilangan peroksida terkecil yaitu $39 \mathrm{Meq} / \mathrm{kg}$ pada volume pelarut $150 \mathrm{ml}$.

Menurut penelitian sebelumnya yang dilakukan oleh Anie Komayaharti dan Dwi Paryanti,"Semakin banyaknya volume solvent, maka semakin besar larutan yang di ekstrak. Dengan demikian maka semakin banyak senyawa yang dapat keluar dari dinding sel yang diekstrak. Akan tetapi suatu pelarut memiliki kemampuan terbatas dalam menarik senyawasenyawa dari suatu bahan, sehingga setelah dicapai kondisi maksimum maka solvent tidak mampu lagi meyerap senyawa dari bahan yang di ekstrak, sehingga ekstraksi diteruskan maka hasilnya akan konstan".

Pada percobaan ini diperoleh bahwa volume pelarut maksimum pada variasi kecepatan pengadukan $100 \mathrm{rpm}$ adalah pada 150 $\mathrm{ml}$ dan konstan sampai $200 \mathrm{ml}$ volume pelarut pada waktu ekstraksi 75 menit dengan bilangan peroksida terkecil mencapai $42 \mathrm{Meq} / \mathrm{kg}$. Sedangkan pada kecepatan pengadukan $300 \mathrm{rpm}$ diperoleh volume pelarut maksimum adalah 150 ml tetapi waktu ekstraksi yg paling baik adalah pada waktu 60 menit dengan bilangan peroksida terkecil yaitu $39 \mathrm{Meq} / \mathrm{kg}$.

Apabila telah mencapai kondisi maksimum maka solvent tidak mampu lagi menyerap senyawa dari bahan yang diekstrak, sehingga ektraksi diteruskan maka hasilnya akan konstan. Setelah hasil ekstrak dihasilkan yang konstan, maka eugenol yang dihasilkan juga akan tetap sama walaupun proses ekstraksi diteruskan sehingga kemampuan eugenol untuk berikatan dengan radikal bebas akan menghasilkan nilai bilangan peroksida yang sama.

Percobaan ini telah sesuai dengan teori yang ada karena hasil yang diperoleh konstan setelah mendapat kondisi maksimum.

\subsection{Bahan Baku Serbuk Kering Daun Sirih Merah}

2.1.1 Pengaruh Volume Pelarut Terhadap Bilangan Peroksida

Grafik-grafik di bawah (Gambar 5 dan Gambar 6) menunjukkan pengaruh volume pelarut dan waktu ekstraksi terhadap bilangan peroksida. Volume pelarut dapat mempengaruhi banyaknya antioksidan yang diperoleh dari ekstraksi serbuk kering daun sirih merah pada kecepatan pengadukan $100 \mathrm{rpm}$ dan $300 \mathrm{rpm}$. Semakin rendah bilangan peroksida yang diperoleh berarti antioksidan yang dihasilkan dari ekstrak serbuk kering daun sirih itu tinggi.

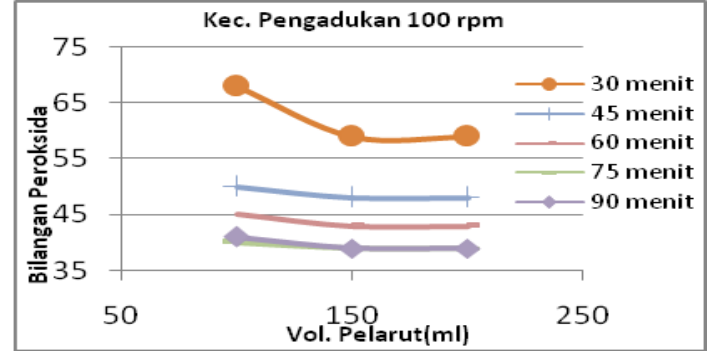

Gambar 5. Grafik Pengaruh Volume Pelarut terhadap Bilangan Peroksida pada Serbuk Kering Daun Sirih Merah (Kecepatan Pengadukan 100 rpm).

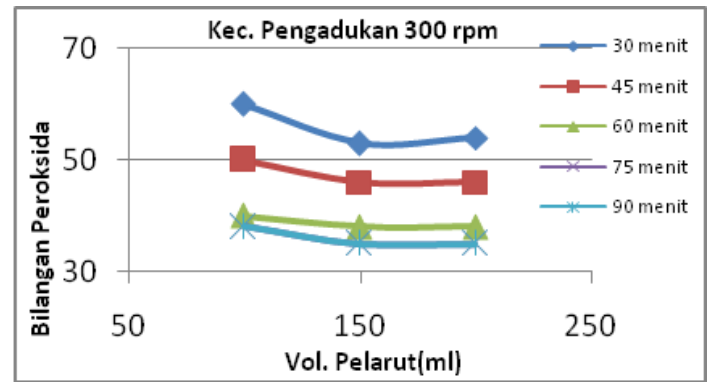

Gambar 6. Grafik Pengaruh Volume Pelarut terhadap Bilangan Peroksida pada Serbuk Kering Daun Sirih Merah (Kecepatan Pengadukan 300 rpm).

Untuk mengetahui pengaruh volume pelarut terhadap bilangan peroksida dengan kecepatan pengadukan $100 \mathrm{rpm}$ dan $300 \mathrm{rpm}$ pada serbuk kering daun sirih merah, dilakukan sejumlah percobaan dengan variasi volume pelarut (v) 100 $\mathrm{ml}, 150 \mathrm{ml}$, dan $200 \mathrm{ml}$ dengan waktu (t) antara: 30 menit, 45 menit, 60 menit, 75 menit, dan 90 menit.

Pada kecepatan pengadukan $100 \mathrm{rpm}$ dan 300 rpm dengan variasi waktu 30 menit, 45 menit dan 60 menit diperoleh diperoleh penurunan bilangan peroksida yang tidak terlalu signifikan. Pada kecepatan pengadukan $100 \mathrm{rpm}$ dan 300 rpm dengan waktu ekstraksi 75 menit diperoleh bilangan peroksida terkecil sebesar 39 $\mathrm{Meq} / \mathrm{kg}$ dan $35 \mathrm{Meq} / \mathrm{kg}$.

Menurut penelitian sebelumnya yang dilakukan oleh Anie Komayaharti dan Dwi Paryanti,"Semakin banyaknya volume solvent, maka semakin besar larutan yang di ekstrak. Dengan demikian maka semakin banyak senyawa yang dapat keluar dari dinding sel yang diekstrak. Akan tetapi suatu pelarut memiliki kemampuan terbatas dalam menarik senyawasenyawa dari suatu bahan, sehingga setelah dicapai kondisi maksimum maka solvent tidak mampu lagi meyerap senyawa dari bahan yang di ekstrak, sehingga ekstraksi diteruskan maka hasilnya akan konstan".

Pada percobaan ini diperoleh bahwa volume pelarut maksimum adalah pada $150 \mathrm{ml}$ 
volume pelarut dan konstan sampai $200 \mathrm{ml}$ pada waktu ekstraksi 75 menit dan konstan 90 menit untuk kecepatan pengadukan $100 \mathrm{rpm}$ dan 300 rpm.

Apabila telah mencapai kondisi maksimum maka solvent tidak mampu lagi menyerap senyawa dari bahan yang diekstrak, sehingga ektraksi diteruskan maka hasilnya akan konstan. Setelah hasil ekstrak dihasilkan yang konstan, maka eugenol yang dihasilkan juga akan tetap sama walaupun proses ekstraksi diteruskan sehingga kemampuan eugenol untuk berikatan dengan radikal bebas akan menghasilkan nilai bilangan peroksida yang sama.

Percobaan ini telah sesuai dengan teori yang ada karena hasil yang diperoleh konstan setelah mendapat kondisi maksimum.

\section{Kesimpulan}

1. Keadaan optimum pada serbuk kering daun sirih hijau adalah pada volume pelarut $150 \mathrm{ml}$, waktu ekstraksi 60 menit dan kecepatan pengadukan $300 \mathrm{rpm}$ dengan bilangan peroksida yang diperoleh sebesar $39 \mathrm{Meg} / \mathrm{kg}$.

2. Keadaan optimum pada serbuk kering daun sirih merah adalah pada volume pelarut 150 ml, waktu ekstraksi 75 menit dan kecepatan pengadukan $300 \mathrm{rpm}$ dengan bilangan peroksida yang diperoleh sebesar $35 \mathrm{Meg} / \mathrm{kg}$.

3. Keadaan optimum pada daun sirih hijau segar cacah adalah pada volume pelarut $150 \mathrm{ml}$, waktu ekstraksi 75 menit dan kecepatan pengadukan $300 \mathrm{rpm}$ dengan bilangan peroksida yang diperoleh sebesar $57 \mathrm{Meg} / \mathrm{kg}$.

4. Keadaan optimum pada daun sirih merah segar cacah adalah pada volume pelarut 150 ml, waktu ekstraksi 75 menit dan kecepatan pengadukan 300 rpm dengan bilangan peroksida yang diperoleh sebesar $51 \mathrm{Meg} / \mathrm{kg}$.

\section{Daftar Pustaka}

[1] Andarwulan, Nuri dkk, Pemanfaatan limbah minyak atsiri daun sirih. http://smk3ae.wordpress.com. Diakses tanggal 5 September 2010.

[2] Komayaharti, Anie dan Dwi Paryanti, Ekstrak daun sirih sebagai antioksidan pada minyak kelapa, 2009. http://eprints.undip.ac.id. Diakses tanggal 20 Agustus 2010.

[3] Jcojac, Pengaruh bahan makanan awet terhadap kanker, 2008. http:// www.scribd.com. Diakses tanggal 18 November 2010

[4] Ketaren, Minyak dan Lemak Pangan, 1st ed, Universitas Indonesia, Jakarta, 1986.

[5] Kumalaningsih, Sri, Antioksidan Alami, Trubus Agrisarana, Surabaya, 2006.

[6] Laitupa, F. Perhitungan Bilangan Peroksida, http://eprints.undip.ac.id. Diakses tanggal 20 Agustus 2010.

[7] Oyinayashi, Manfaat daun sirih merah http://oyinayashi.blogspot.com. Diakses tanggal 1 September 2010.

[8] Rahayu, Suparni Setyowati, Teknologi Proses Ekstraksi. http://www.chem-istry.org. Diakses tanggal 5 September 2010.

[9] Wardhanu, Adha Panca. Antioksidan alami sumber dan pemanfaatannya. http:// apwardhanu.wordpress.com. Diakses tanggal 1 September 2010.

[10] Wijana dkk. Standar mutu minyak goreng berdasarkan SNI 3741-1995. http://www.scribd.com. Diakses tanggal 5 September 2010.

[11] Wikipedia, Sirih hijau. http:// id.wikipedia.org. Diakses tanggal 18 November 2010 